\title{
Comparing dispositifs in Bismarckian Welfare States
}

Yoann Boget

Doctorant, EHESS

Centre Maurice Halbwachs

Équipe de Recherche sur les inégalités sociales 


\section{RSA and Hartz IV - Convergence and Divergence}

Comparative research on welfare states is facing various pitfalls in our days. This article is concerned with a particularly tricky issue by considering scholastic effects of thinking welfare provision in terms of typologies, such as the one developed by Esping-Andersens in his study on The Three Worlds of Welfare Capitalism. This study still is an indispensable reference for comparative research on social protection schemes. True, since the publication of EspingAndersen's famous approach to social welfare systems, a very broad range of studies has aimed at criticizing, adjusting or extending his approach (Esping-Andersen 1996, Pierson 2001, Palier 2004, Bonoli 2006, etc.). Nonetheless, studies on the evolution of these schemes, and especially those concerning the development of the so-called Bismarckian (or corporatist) welfare regime, have tended to consider these different 'worlds' as a homogenous unit sharing a common developmental logic, generally referred to as path dependency (Clasen and Clegg, 2006; Palier and Marin, 2008; Palier, 2010). However, this perspective hides the variety of programs established in this regime and impedes an understanding of the differences among welfare states belonging to the same 'world'. Against this background, this article offers a detailed analysis of the evolution of minimum-income benefits schemes (MIBs) and related social policies in France and Germany. Shedding light on Bismarckian welfare states, such an analysis shows that there is significant variation among the two welfare states, despite their seemingly common development.

The article is organized as follows: first, I will review the literature on the topic, elucidating the aforementioned theoretical framework and its pitfalls, together with tentative suggestions of how to avoid them. Secondly, I will describe the recent historical evolution of MIBs in Germany and France, with an eye on its increasing role within the two welfare regimes. Thirdly, I will focus on two recent reforms, namely the so-called 'Hartz IV legislation in Germany and the 'RSA' reform in France. I will present these policies through a lens on the rationality of what I refer to as dispositifs (Foucault, 1997). I will argue that, on the one hand, the same axiological rationality (Wertrationalität, in the terms of Max Weber) is instilled in the French and German MIB schemes, with the predominance of the market as the privileged instrument for regulating poverty and precarious living conditions. On the other hand, however, these programs differ from each other in their instrumental rationality (Zweckrationalität), that is, by the fact that the French MIB scheme places great emphasis on financial incentives while the German model is based on disciplinary instruments.

\section{A common path towards dualization?}

'Bismarckian' welfare regimes have been described as being particularly hard to reform (EspingAndersen, 1996); and indeed, unemployment insurance has not been dismantled or radically restructured over the last years, with change being confined to but minor revisions (Barbier and Knuth, 2011). However, the social protection schemes dealing with unemployment have changed profoundly in both France and Germany. On the one hand, this was a consequence of severe turbulences on the labour market. On the other hand, change in unemployment protection schemes resulted from important reforms of MIBs, being considered by many as leading into a dual welfare state (Bleses and Seeleib-Kaiser, 2004; Palier and Martin, 2008).

Few studies have examined this transformation of 'Bismarckian' welfare regimes comparatively. Most work in the field has adopted either a global perspective or a focus on mere labour market policies. Either way, this work comes to the same conclusion: the evolution of the Bismarckian welfare states is characterized by a similar process of dualization. Thus, in their book entitled Reforming the Bismarckian Welfare Systems, Palier and Martin (2008) argue that similar institutional designs have entailed similar reforms, and consequently the same process of dualization across the respective social protection schemes. "The Bismarckian welfare systems are being changed by the current reforms. It is too early to know whether this means a structural transformation of the systems as such. However, we can already identify a process of dualization of the welfare system, as well as of the population 
protected. (...) This dualization also means that the whole population is not covered any more by the same principles and institutions. " (16) In their analysis, they insist on the importance of the political impetus behind this dualization. What is left out of the picture here is the fact that the dualization of welfare states far and wide results from a similar transformation of the labour market in both France and Germany, for instance through growing rates of unemployment and the development of atypical work (Neumann 2004a). Whereas recent contributions to the debate like, the one by Palier (2010), point out general principles that are applied to the instruments of welfare states, more specific comparative work dealing with programs related to unemployment, such as Neumann (2004b) or Clasen and Clegg (2006), shows that the MIBs, becoming more and more important, have progressively superseded insurance-based protection schemes. Yet again, while such authors argue that the dualization of the welfare state is obvious in the field of unemployment protection, they conclude - like the studies adopting a more general perspective - that respective programs for jobseekers in France and Germany follow the same development.

This conjecture of a common dualization of Bismarckian welfare regimes is debatable at least for three reasons. The first issue is about what exactly is meant by dualization. Is it correct at all to describe the evolution of Bismarckian welfare states in the aforementioned terms? The second query concerns the assumption of path dependency. Does dualization imply that Bismarckian welfare regimes are no longer governed by Bismarckian principles? In other words, does dualization stand for path departure? The third issue is concerning the alleged similarities of the reforms under study here. Are these reforms in France and Germany similar or not?

Regarding the first issue, those defending the dualization thesis argue that the working population is not covered by the same institutional principle any more. Yet following Clasen and Goerne (2011), there has never been a situation in which the entire workforce was protected by the same program. This is why they maintain that there are two different ways to interpret dualization: either as a shrinking of the relative size of the group covered by social insurance and a growth of the population covered by social assistance, or as an exacerbated division of two groups that had been separated long before. Adopting to the latter view, the authors argue that it is hard to maintain that dualization is a new strong structural trend in Germany (put aside some minor dynamics which are new in kind). Actually, since the 1960's in Germany and the 1970's in France, there have been several national programs to support poor or unemployed citizens. While this critical perspective does not deny a process of dualization, it shows that one needs to be precise and careful in the definition of what is meant by this term.

The second issue pertains to the meaning of change: Does the recent transformation of the Bismarckian welfare states imply path departure or just a gradual evolution occurring with unchallenged path dependency? The problem here is that there are at least two interpretations of path dependency, and consequently of what is meant by path departure. On the one hand, the concept of path dependency can mean that the original principles still govern the existing institutional set-up. Endorsing this understanding, proponents of the dualization thesis describe the respective development as path departure. Thus, Palier (2010) is speaking of a 'paradigmatic shift' leading to 'a long goodbye to Bismarck'. In contrast, Clasen and Goerne contest the idea of path departure, arguing that social insurance schemes have remained central to Bismarckian welfare states. On the other hand, path dependency could mean that past institutional structures predetermine the development of current institutions. From this perspective, path departure would be interpreted as cultural change. There are two conditions for such path departure: First, it would require political reform; secondly, changes in countries following the same path dependency could differ.

Here a third issue becomes relevant, that is, the similarity of changes across welfare states belonging to the same regime type. The proponents of the dualization thesis claim that Bismarckian welfare states are seeing similar developments. Regarding France and Germany, there are only few voices arguing that the development of MIBs results from distinct rationales. Thus Barbier \& Knuth (2011: 15) note that "close comparison reveals vast differences between 
the two countries with regard to the welfare cultural framing of their MIBs, the positioning of these benefits within the respective governance structure, and the timing and sequencing of reforms.'

One can see, then, that the dualization thesis is debated heavily, with the nature of changes being a basic theme. Yet do Bismarckian welfare regimes exhibit the same path dependency or not? To clarify the issue, this article examines the evolution of social protection schemes for jobseekers in France and Germany. The precise question is: Do German and French programs targeting the unemployed follow the same process of dualization? It will be argued that while the dualization of unemployment protection is a common feature - as segmentation is matter of fact in both countries -, the two countries differ in that the reforms endorsing dualization have brought about distinctive characteristics to the respective programs.

To deal with this issue, a crystal-clear definition of dualization is required. The expression 'dualization of welfare states' as such does not carry much sense. Actually, a welfare state is a set of institutions or programs aimed at protecting citizens against specific social risks. It does not appear adequate to think dualization without reference to the social risk concerned. In other words, it is not the welfare states itself that become dual but the way they are dealing with a given social risk. In this contribution, then, dualization means that a growing and significant part of the population is not protected against the same social risk by one core program.

Most studies on the issue of dualization confer a central role to the reforms of unemployment insurance. Yet while the related programs have been contained over the last 20 years, they have not been transformed fundamentally. Actually, the most important change is concerning the role of MIBs. These benefit schemes, introduced to provide financial support to the poorest by offering them an allowance inferior than all other welfare benefits, were established as a key instrument of French and German social policies regarding the management of unemployment. The dualization of the respective protection schemes is not a result of a split of the welfare state or of a incidental growth of marginal social protection schemes. Rather, it follows from programs against poverty becoming reoriented towards labour market policy. In other words, dualization proceeds by the transformation of MIBs and their integration into social protection against the risk of unemployment.

Understanding these changes implies understanding the evolution in how programs are being defined. It has partially to do with political, academic, and expert discourse about MIBs, but the overall evolution is also 'actualized' through legislative reforms. This article provides neither a discourse analysis nor an enquiry on legal provisions. It seems more relevant in the aforementioned context to study the MIBs as dispositifs (or apparatus for social policy). Following Foucault's classical definition, a dispositif is an 'ensemble consisting of discourses, institutions, architectural forms, regulatory decisions, laws, administrative measures, scientific statements, philosophical, moral and philanthropic propositions (...)'. These different elements are not distinguished further in the dispositif: laws are discourses that are administrative measures that adopt an architectural form that consists of institutions that are moral and philanthropic propositions. Foucault suggests that 'the apparatus itself is the system of relations that can be established between these elements'. Hence the dispositifs ensure the coherence of a system of relations; it is the logic interlinking its different elements.

The aim of the following analysis thus is to understand this coherence and its transformation. More concretely, the purpose is to comprehend how target groups have been defined by these dispositifs; with which intention; by using which categories and institutions; and by which instruments? Thus, understanding dispositifs is understanding their internal coherence. In other words, my intention is to depict the rationality of the respective policies. Therefore, this article is interested neither by the institutional practice nor by the evolution of social intervention; rather, it focuses on the 'context of meaning' (Sinnzusammenhang) in which this practice or intervention takes place.

My objective, then, is to display the evolution of the rationality inherent to the aforementioned dispositifs, and to explore how they acquire social meaning so as to govern welfare policies 
in France and Germany. In this vain, the dispositifs of MIBs are considered as instruments of government, that is, in Foucaldian terms, 'techniques to conduct the conducts'. Social policy is regarded as a technique of government and as a given rationality at the same time. The concept of governmentality (Foucault, 2001 [1984], 2004, 2008) enables us to think together the coherence of a policy and its concrete expression. In this context, it appears relevant to retrace the evolution of the dispositifs regarding the transformation of the interpretative framework in terms of categorizations, institutions and techniques of social intervention. Thus, I will widely ignore the structure of the institutions, their formal organization, their funding as well as implementation issues (e.g. concerning street-level bureaucracy and effect on recipients). Rather, the focus lies on the rationality of the dispositifs.

First, such analysis emphasizes the common interpretative framing of the unemployment protection schemes in France and Germany. Secondly, it offers tools for elucidating the main dimensions in which the two systems differ. These differences highlight the dissimilar rationality embedded in the policy instruments adopted by each country although one can question the homogeneity of the Bismarckian model as presented in the wider literature. Beforehand, however, it is necessary to trace the origins of the changes these instruments have gone through, by outlining recent developments in the two MIBs systems and locating them with the entire structure of the two welfare states.

\section{MIBs: from poverty-related benefits to 'second-order' unemployment protection}

Against the background of strong economic growth, post-war Western European welfare states developed considerably their social protection systems after World War II, paving the way to the 'wage-earner golden age' (Castel and Laé, 1992). France and Germany set up social insurance as a major instrument for protecting workers. In particular, they introduced very similar unemployment insurance schemes. In contrast, poverty alleviation programs did not go through the same process. In 1961, Germany created a federal framework to cover the population against poverty. As Schultheis (1996) shows, social assistance (Sozialhilfe), offering a minimum income to all citizens in need, was meant to target residual poverty which was considered a disappearing phenomenon for the time being. In France, it took nearly 30 years to see an equivalent program emerge, that is a scheme labeled Insertion Minimum Income (Revenu Minimum d'Insertion, RMI) ${ }^{1}$, which was created in 1989 . The context was very different here as the RMI was geared towards combating what became referred to as 'new poverty' (Paugam, 1991).

Despite the aforementioned differences, both MIBs schemes have been designed as key instruments to fight poverty. Their main objective consists of providing a minimum standard of living to citizens in need, rather than to protect workers against the risk of unemployment. The two welfare states introduced a third type of protection scheme for targeting long-term jobseekers: the unemployment assistance in Germany (Arbeitslosenhilfe, ALH), and the specific solidarity benefit in France (Allocation Spécifique de Solidarité, ASS). These programs funded by tax revenue can be regarded as a specific income support to unemployed people. Hence, institutionally speaking, social protection against unemployment was already dual in the early 1990. However, the insurance scheme covered the vast majority of unemployed people in the two countries at that time.

Thus, during the early 1990's, the social protection systems of both countries exhibited a comparable architecture again which remained unchanged until the mid 2000's (see table 1). There were two instruments for protecting jobseekers - an insurance benefit as core instrument and 'assistance benefits' a juxtaposed protection scheme, whereas MIBs were meant to tackle poverty. The existence of two assistance schemes - one for the long-term

\footnotetext{
${ }^{1}$ An allowance for single parents (Allocation pour Parents Isolés) already existed but available to single parents only (usually the mother) and delivered until the youngest child turned three
} 
unemployed, the other one for the poor - bear witness to the welfare state having developed instruments for treating two problems separately: employment-related social protection on the one hand (unemployment insurance and assistance), poverty-related protection (MIBs) on the other hand.

Table 1: Pre-reform unemployment protection schemes in France and Germany

\begin{tabular}{|c|l|l|}
\hline & France (2008) & Germany (2004) \\
\hline Unemployment benefits & Assurance chômage & Arbeitslosengeld \\
\hline Level & Min 57,4\%, max 75\% of last wage. & $\begin{array}{l}60 \% \text { of last wage (67 with } \\
\text { dependent child) }\end{array}$ \\
\hline Duration & 23 month max. (36 month over 50) & Variable but max 32 month \\
\hline Financing & Contribution & Contribution \\
\hline Number of recipients & 1.7 mio & 1.8 mio \\
\hline Unemployment assistance & Allocation spécifique de solidarité & Arbeitslosenhilfe \\
\hline Level & $448 €$ & $\begin{array}{l}53 \% \text { of last wage (57\% with } \\
\text { dependent child) }\end{array}$ \\
\hline Duration & $\begin{array}{l}\text { Open-ended (As long as recipients worked } \\
5 \text { years during the last } 10 \text { years) }\end{array}$ & $\begin{array}{l}\text { Open-ended (-3\% of the allowance } \\
\text { each year) }\end{array}$ \\
\hline Financing & National tax revenue & Federal tax revenue \\
\hline Number of recipients & 324,000 & 2.2 mio \\
\hline Minimum Income Benefits & Revenu minimum d'insertion & Sozialhilfe \\
\hline Level (for single) & $448 €$ & $\begin{array}{l}297 € \text { max. + housing costs }+ \\
\text { evidence need }\end{array}$ \\
\hline Duration & No limit & No limit \\
\hline Financing & National tax revenue & Federal tax revenue \\
\hline Number of recipients & 1.1 mio & 2.9 mio \\
\hline
\end{tabular}

During the 1990's, the number of citizens depending on the assistance programs was growing considerably, given a new crisis on the labour market. As there was no policy change, these programs de facto became the last resort for an increasing number of citizens. Both the deregulation of labour law and the constant progression of long-term unemployment were boosting the number of people not entitled to unemployment benefits (Audier, Dang et Outin, 1998). Comparison between the evolution of the number of workers receiving insurance benefits and those on welfare (assistance benefits) confirms that the two phenomena were strongly connected.

\section{Recipients of social protection benefits in Germany}

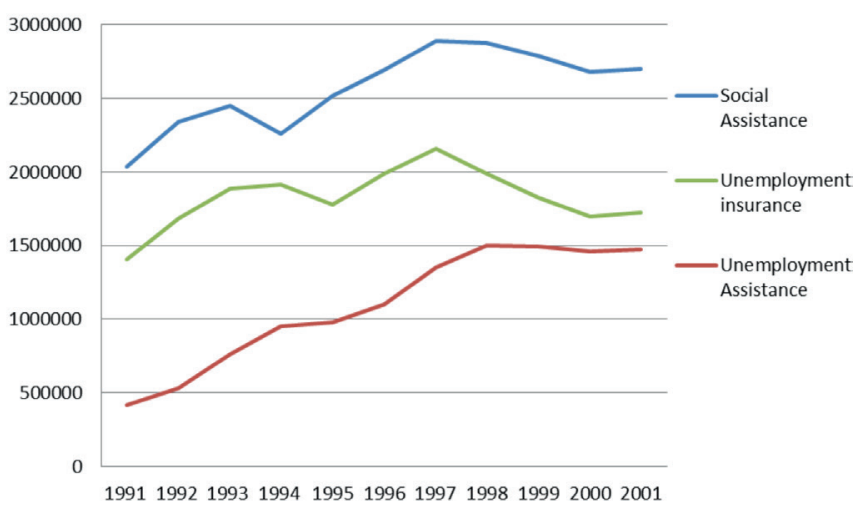

Graphic 1. Source: BMAS

(Ministry of Work and Social Affairs)

Own calculation and design 
The aforementioned programs followed an analogous trend. After a strong growth in the first half of 1990's, the number of recipients remained stable at a high level in the second half of the 1990's and in the early 2000's (see graphic 1 and 2). One can say then that the transformation of the labour market, and particularly what Castel (1995) has referred to as 'the erosion of the wage-earner condition' ('effritement de la condition salariale) have contributed greatly to the exclusion of an increasing number of people from (steady) employment and from traditional insurance-based protection, as well as to the extension of precarious life trajectories, according to Castel and Dörre (2009).

\section{Recipients of social protection benefits in France}

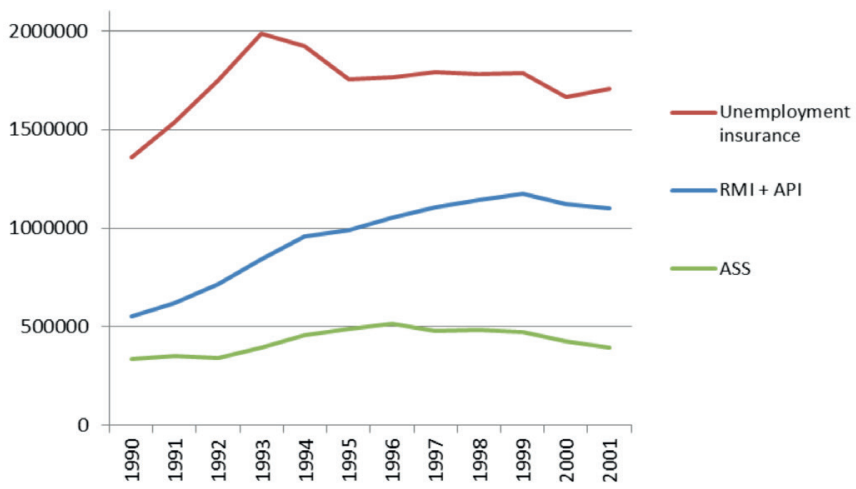

Graphic 2. Sources: INSEE and Pôle Emploi, Own Calculation and design.

The strong progression of assistance benefits in protection schemes for jobseekers changed markedly the role of the various dispositifs in the French and German welfare state. Social assistance gained prominence as a central instrument of social policy, thus causing a legitimacy crisis. The unexpected expansion of the assistance benefits inevitably changed the way of thinking social policy, with institutional change as a logical consequence. Accordingly, during the late 1990s and the early 2000s, new concepts emerged for describing the transformation of welfare states in general and of unemployment protection in particular. Some spoke of workfare (Trickey and Lødemel, 2000), others of a conditionality of social rights (Outin, 1996; Dufour and al., 2003) taking shape. Yet it is the notion of 'activation' that tends to stand out in the academic as well as the political field (Barbier, 2008, 2009).

The aforementioned terms refer to different conceptions regarding the support granted to jobseekers. At the same time, they denote diverging realities and various standpoints vis-à-vis these realities. Within the confines of this article, it is impossible to portray in greater detail the political and scientific dynamics related to this semantic evolution. The point here is that the development of these new concepts has been the expression of a legitimacy crisis in the welfare state; it has paved the way to attempts of imposing new representations regarding the dispositifs for unemployed people. The result is a far-reaching transformation of how social policies are conceived of in the light of these developments, particularly concerning jobseekers. Following Serrano Pascual, one can describe these important changes as a paradigmatic shift (2007) remodeling the instruments of social regulation, especially by redefining social citizenship in contractual terms and by an emphasis placed on micro-economic efficiency.

The key element to this paradigmatic shift is the abandonment of the distinction between unemployment and poverty in social policy as it had been established in former times. The employment policies that traditionally were focused on the recipients of unemployment benefits are now targeting the recipients of the MIBs, too. This is particularly striking as these dispositifs were not relevant that much until then. In other words, the innovation these policies have brought about consists of applying techniques hitherto focused on jobseekers to recipients of MIBs, to a point that these dispositifs have become an integral part of labour market policy, with this being prone to change the meaning of the relevant programs radically. 
In the same vain, anti-poverty policies changed under the influence of these new conceptions. The instigation of a real conditionality to social rights, pointed out by Duvoux (2009), is only the most obvious expression of the changes underway. For this shift remodels the rationality governing the respective policies. The latter no longer are evaluated with the mere perspective of combating poverty and to integrate socially excluded citizens. Rather, with the new conceptions, they are assessed by considering their impact on the labour market. While modern social policy has always been geared towards the empowerment of addresses so to reintegrate them in the labour market, the current policy perspective is distinctive in kind. The prevailing objective now is to prevent that social protection schemes, by their incentive structure, set limits to people moving back into gainful employment.

Hence new techniques appear, sometimes replacing classical measures for social reintegration (Schuldt, 2008), and with the mere aim of pushing jobseekers to enter the labour force. MIBs become an important element among the instruments regulating the labour market and thus contribute to the restructuration of the latter. The unemployment question is superimposed on the issue of poverty in such way that MIBs and unemployment insurance become two different modalities of managing unemployment.

\section{RSA and Hartz IV: The enactment of a new axiological governmentality}

The conceptual shift regarding social protection against poverty has unavoidably led to important modifications in MIB schemes so much that it nowadays appears more appropriate to consider them as employment policies addressing poor and precarious citizens, rather than as instruments for combating poverty. France is a case in point. In 2009, the introduction of the Active Solidarity Income (Revenu de Solidarite Active), replacing the former RMI together with an allowance for single parents, the so-called API (Allocation pour Parents Isolés) - has brought further profound change to the social protection system. Likewise, in Germany, reforms enacted under the label "Hartz" have reorganized entirely this system between 2003 and 2005. Last but not least, the so-called Hartz IV reform abolished the ALH and large sections of the former social assistance program (Sozialhilfe) by a new scheme coined 'Unemployment Benefit II' (Arbeitslosengeld II). In Germany, the reform reveals a process of hybridization between employment-related benefits and poverty-related benefits. In France, the ASS was not abolished; the number of recipients has remained stable at a relative low level (355'000 at the end of 2010). However, the RSA reform has brought to the MIB scheme a whole range of changes pertaining to employment issues.

The two reforms have common features. In both countries, they are the most important changes to the welfare regime over the last 20 years (see table 2). There is the same tendency of making anti-poverty programs become an integral part of labour market policies. In both cases, the key objective is moving recipients back to gainful employment through a system of 'sticks and carrots', even at the cost of increasing the number of precarious workers in the lower stratum of the labour market. Thus, the introduction of Hartz IV and the RSA bears witness to a new rationality conferred upon the respective dispositifs. The reforms institutionalize a novel way of thinking social policy as they enact a new governmentality. Using basic elements from Max Weber's social theory and applying them to the Foucaldian framework, one can say that they establish the same axiological governmentality (Wertrationalität). In both cases, this governmentality is impregnated with the idea of integrating anti-poverty programs into labour market policies and by the intention of moving recipients on welfare back into gainful employment by a set of incitements and constraints. In other words, the aim in both countries is to prioritize market regulation over social state regulation. However, as one can see below, the two dispositifs are distinctive in an important respect, that is, regarding their instrumental rationality (Zweckrationalität). 
Table 2: The systems of social protection 2011.

\begin{tabular}{|c|l|l|}
\hline & France & Germany \\
\hline Unemployment benefits & Assurance chômage & Arbeitslosengeld I \\
\hline Level & $\begin{array}{l}\text { Min } 57,4 \%, \text { max } 75 \% \text { of } \\
\text { the last wage. }\end{array}$ & $\begin{array}{l}60 \% \text { of the last wage (67 with } \\
\text { dependent child) }\end{array}$ \\
\hline Duration & 24 month (36 over 50) & 12 month (24 over 58) \\
\hline Financing & Contribution & Contribution \\
\hline Number of recipients & 2.1 mio & 829193 \\
\hline Minimum Income Benefits & Revenu de solidarité active & Arbeitslosengeld II \\
\hline Level (for single) & $467 €$ & $364 €$ max. + housing costs \\
\hline Duration & No limit & No limit \\
\hline Financing & National revenue & Federal revenue \\
\hline Number of recipients & 2.0 mio (June) & 3.5 mio \\
\hline
\end{tabular}

In the field under review, one can observe changes on three levels: first, the categories for classifying benefit recipients, second institutions taking them in charge, and finally, the techniques implemented for moving recipients towards gainful employment.

The Active Solidarity Income introduces a clear distinction between three categories of recipients: those earning more than $500 €$ per month, those without activity but immediately available to get a job and those facing social difficulties that make job research impossible (temporarily). Hence, the RSA scheme categorizes the recipients according to their employment status. The aim is to deal with most of them as jobseekers. In Germany, changes in the names of the dispositifs' introduced with 'Hartz IV are telling; the assistance scheme carries the same name as the insurance scheme. The two 'unemployment benefits' (Arbeitslosengeld) are not distinguished any further than by their ranks: 1 for the insurance, 2 for the assistance. The subtitle of the respective law points into the same direction by describing 'unemployment benefits II' (Arbeitslosengeld II) as a 'basic security the jobseekers' (Grundsicherung für Arbeitsuchende). Knuth (2006) argues that this implicitly refers to a particular status, that of an unemployed person or a jobseeker, although the assistance is granted in terms of needs, i.e. by means-tests. In fact, the law is written in such a way that all recipients are viewed as jobseekers, thus denying the existence of people who perceive the allowance on top of income from professional activities, as well as of those who are temporarily unable to move back into the labour market.

One can observe a similar transformation in the institutions that administer the beneficiaries. In France, benefit claimants who are employed are exempted from what is referred to as 'accompaniment'. Those who are considered as immediately employable are 'serviced' by the employment agencies (Pôle Emploi). Only citizens facing particular social difficulties are directed towards the social 'insertion service'. In Germany, due to a lacking consensus when the law was voted, the institutions in charge depend of the area (with social welfare departments of local authorities being entitled to work with those on 'unemployment benefit II' exceptionally). The jobcentres (Arbeitsagentur, a national agency that depends on the Federal Minister of the economy and employment) play the key role for the dispositif. For the two countries, one can they then that those institutions that have traditionally been in charge of jobseekers dominate the system when it comes to the 'administration' of MIBs recipients.

Finally, the two countries have introduced a whole range of new methods that, rather than seeking to improve the employability of recipients, directly encourage, not to say compel, recipients to take up jobs available on the (regional) labour market. In other words, the reforms have orchestrated various welfare-to-work instruments. Indeed, some of the new measures are aimed at containing as much as possible the influence of MIBs by letting the market play 
a greater role in the regulation of poor and precarious citizens. Among these measures, one can mention eligibility rules requiring 'active participation' in job-seeking as a condition for income support. In addition, in both countries, the dispositifs embrace provisions through which recipients can be forced to accept 'proposals' for employment. A system of sanctions confers a mandatory character on these provisions. In the same vain, reforms in France and Germany have created schemes through which welfare benefits and earned income can be cumulated. Following the mantra of 'making work pay', the leading principle is that work should always be more attractive financially than receiving just the allowance. Overall, it is obvious that, regarding the new repertoire of interventions vis-à-vis benefit recipients, there are various measures that seek to delimit the role of welfare benefits in the regulation of the labour market.

Beyond the differences between the two systems illuminated in the next section, similar intentions are governing the reforms of the French and German unemployment protection scheme. This pertains to those categories by which recipients are defined, the agencies in charge of them, and the methods they use; all show that there is a common rationality for controlling the conduct of jobseekers and ensure market regulation. The way of defining recipients, agencies and techniques bears witness to what Knuth (2006) already suggested for the German case: the merger of employment policies and anti-poverty policies. The reforms of MIBs exhibit a profound shift in how these dispositifs are perceived. The interdependency of the two policies is revealed particularly by the categorization of recipients according to their (un-)employment position, by the organization of the jobseekers' 'supervision', and by the techniques of intervention that seek to constrain the role of benefits within the lower stratum of the labour market. In other words, the basic transformation consists of the creation of new techniques that make unemployed citizens accept jobs that they would otherwise not have applied to spontaneously.

\section{Two types of instrumental governmentalities}

While the values encapsulated by the new dispositifs in France and Germany follow the same axiological governmentality, there are differences in what has been referred to as 'conduct of conducts' regarding the methods of social intervention in the field of unemployment protection. Although the techniques applied show strong similarities, the means used for their implementation prove highly diverse. They give strong reasons to differentiate contemporary Bismarckiens welfare states on the basis of to two different types of instrumental governmentality.

In fact, one can distinguish two types of "conduct of the conducts'" here: disciplinary techniques and financial incentive techniques. The disciplinary techniques are enclosed in the statement of obligations agreed or fixed in advance during the 'service encounter' at the jobcenter (or other agencies). This statement defines provisions by which the recipients must obey. They are based on the triptych: obligation, control and sanction. The obligations work only because they are related to a control of the established duties, followed by sanctions in case of non-respect. The disciplinary techniques are modeled on the idea of penalty: the more numerous, detailed, and constraining the obligations, the more rigorous controls; the more detailed, quickly applicable and heavier the sanctions, the greater the disciplinary effect of the dispositif. The financial incitements are based on the assumption that the target groups of these policies are driven by the rationality of a homo œconomicus. Postulating this rationality, the aim of the dispositif simply is to improve the attractiveness of job-seeking. The weaker the benefits, the better are opportunities for cumulating the allowance with earned income, and the more incitivizing the dispositif will be considered.

According to these ideal type distinctions, France has put greater emphasis on financial incitements. The heart of the RSA reform consisted of favoring low-wage employment by complementing the income of the working poor. This mechanism echoes the 2007 campaign slogan of Nicolas Sarkozy 'work more to earn more' ('travailler plus pour gagner plus'). Germany falls under another logic. The mantra here is 'support and challenge' ('Fördern und Fordern'), 
with the respective laws translating this orientation into distinctive provisions. Although the two metaphors are not totally comparable with each other (Sarkozy's one was a formula addressing all sorts of citizens, whereas the German slogan was specifically targeted on longterm jobseekers), both give expression to the main distinctions between the two systems at present. Indeed, as a systematic comparative analysis of the MIBs will show, two patterns of instrumental governmenttality can be distinguished (Boget, 2013).

\section{1 « Fördern und fordern » : the disciplinary techniques}

In the mantra of "Fördern und Fordern ", the emphasis is placed upon new duties imposed on welfare recipients. In fact, the new German legislation insists vigorously on obligations for recipients and defines them very precisely. Claimants have to do anything they can to delimit or to terminate their dependence on MIBs. They must sign an integration agreement (Eingliederungsvereinbarung) that specifies 'efforts' (Bemühungen) expected from them when trying to move back into gainful employment, including the frequency of actions taken and ways to prove their accomplishment. Hence the agreement not only delineates the duties but also the methods of control related to them. Recipients have to accept (almost) any job on offer. The law includes a list of reasons viewed acceptable for refusing a job offer. Only for the first months of unemployment, jobs not corresponding to formally acquired skills or to the previous activity of the jobseeker can be refused. Further reasons for refusal are jobs far away from home or paid much less than on average. The law also contains a provision urging jobseekers to participate in 'work opportunities' (Arbeitsgelegenheiten), that is, petty jobs paid between one and two $€$ per hour concurrently with the allowance (Wolff and Hohmeyer, 2006). Compared with the French legislation, the German law provides obligations that are more numerous, more constraining and more precise.

The respective regulation in France leaves very large scope of discretion to local decisionmakers. Welfare recipients, as far as they are immediately able to work, have to follow the same rules as each jobseeker. This implies positive and repeated job-seeking, and the interdiction 'to decline more than two reasonable' job offers. The law also stipulates that a recipient whose work income exceeds $500 €$ per month is not subject to any duties. Beneficiaries who are not immediately available for work have to take steps for their social and professional integration. True, it would be misleading to assert that recipients have no duties, but the obligations are soft. They leave space for negotiation (with jobcenter agents) and they largely depend on the interpretation of decision-makers.

The same applies to the penalty scheme. In France, decisions concerning sanctions, their level and their length lie with the president of general council (the executive of department), after deliberation with a special commission (équipe pluridisciplinaire). Penalties depend on local agents. Moreover, social law sets limits regarding their level (100 €) and their length (from 1 up to four months). The German law is stronger in this respect, too. Sanctions are defined precisely and have to be applied directly by the jobcenter agent here. Regardless of the offense committed, cuts of $30 \%$ allowance apply in case it is the first offense, of $60 \%$ if it occurs a second time, and $100 \%$ afterwards. The length of the penalties is always three month. Even conducts that are not explicitly prohibited can be punished, such as missing an appointment or exhibiting 'uneconomic behavior' (unwirtschaftliches Verhalten).

Compared to France, then, the penalties are much more severe in the German dispositif (Müller and Oschminasky, 2005). As Aust (2008) has outlined, the system of duties and penalties is an essential characteristic of the German MIBs. Oschmiansky and al. (2007) characterize this program as an authoritarian-activating employment policy (autoritäraktivierende Arbeitsmarktpolitik). This character is not totally absent in France but it is not playing such an important role. 


\section{2. "Travailler plus pour gagner plus»: techniques of financial incentivization}

The comparison of the level of the benefits granted to welfare recipients is not as easy as it looks at first glance. In France, the allowance comprises only a flat-rate allowance. There is a specific housing assistance in addition of the RSA but the beneficiaries of this assistance receive a reduced rate (see table 3 ). Moreover, they have always to pay part of the housing costs. Last but not least, the calculation of the housing allowance underestimates real rent levels ${ }^{2}$, which increases substantially the portion recipients have to pay their own. Beyond a certain threshold, the entire expenditure has to be borne by beneficiaries anyway.

In Germany, the Unemployment Benefits // includes, in addition to the flat-rate allowance, the entire outlays incurred for housing and some other expenditure (unless apartments are oversized). On average, each recipient receives for his family $345 €$, i.e. $192 €$ per dependent person. As for the MIB, for single persons, the flat-rate allowance amounts to $475 €$ in France and $374 €$ in Germany. Including everything, however, the total income support is higher in Germany. For greater families, the difference appears particularly strong. For example, a couple with two children (between 6 and 12 years old) would perceive $997 €$ in France and $1212 €$ in Germany. However, German parents do not receive family benefits. That said, in European perspective, it is generally agreed that France offers relative low minimum income benefits (Concialdi, 2004).

Table 3: Allowance 2012 for different family types (in euros)

\begin{tabular}{|c|c|c|}
\hline & France & Germany \\
\hline Single & $\begin{array}{c}475 \\
\text { or } \\
418+\mathrm{APL}\end{array}$ & $\begin{array}{c}374+\text { housing costs } \\
\text { Average housing costs }: 192374 \\
+192=566\end{array}$ \\
\hline Couple & $\begin{array}{c}712 \\
\text { or } \\
598+\mathrm{APL}\end{array}$ & $\begin{array}{c}674+\text { housing costs } \\
\text { Average housing costs: } 384674 \\
+384=1058\end{array}$ \\
\hline
\end{tabular}

The comparison of how the schemes are dealing with income from gainful employment is much easier. The financial incentives have become a key instrument of French social policy. Like with the former RMI, benefits and income from work may be combined completely during the first three months of employment. However, the principle introduced with the RSA is openended accumulation making it possible to receive wages and social assistance concurrently. The RSA is divided into two parts. The so-called "RSA socle" provides a basic minimum income. The second part, called 'RSA activité' is meant to be a financial incentive to take up work. Through this scheme, recipients of RSA could continue to perceive a part of the allowance while working, up to a net income amounting to $62 \%$ of the gross income. Even young citizens under 25 who are normally excluded of the RSA can take advantage of this financial incentive after two working years. ${ }^{3}$

In Germany, the respective incentives are much less important. The first $100 €$ can be received together with the allowance. As regards revenue higher than this, only $20 \%$ of the gross income may be combined with the allowance, up to $800 €$ ( $10 \%$ up to $1200 €$ ). The aim is less to make work pay but to cover the mere costs related to employment. Overall, it is obvious that the 'carrots' are much more developed in France.

The German state has created programs for work integration meant to encourage recipients to move back to salaried employment. These programs include opportunities for testing the employability of jobseekers and are viewed as instrument for combating the exclusion from

\footnotetext{
2 For example, the housing allowance is based on a maximal amount of $285 €$ for a single person in the region of Paris (Ile-de-France), and $344 €$ for a couple.

${ }^{3}$ This dispensation is known as "RSA jeune" (RSA young).
} 
the labour market. The key objective resides in providing an activity to individuals that are excluded from the labour market on a longer term, with the perspective of quick reintegration. The measures are regarded as 'integration activities' with the aim of helping recipients to find a steady job. The so-called 'work opportuneties' (Arbeitsgelegenheiten) comprise two options. With the first one, a person is employed normally via a subsidized fixed-term contract. In the second model that is more widespread, the individual is not employed formally in the sense of the Labour Code. Rather, he or she perceives an unemployment benefit (II) together with a compensation (of 1 or $1.50 €$ ) for the expenses incurred when participating in the measure (for travelling, meals, etc.). This employment, known as '1-euro-job', is thus a variety of work lacking employment status. In any case, it does not open new entitlements to unemployment benefit I. Whatever kind of '1-euro-job' suggested, beneficiaries do not have the right to refuse it. Any refusal may involve a $30 \%$ reduction of the benefit. Hence, these activities chime with workfare.

In France, the key innovation introduced with the RSA was a possibility to receive part of the allowance and to combine it revenue from gainful employment so that taking up work is always financially interesting. The announced objective of the reform was 'making work pay' so as to encourage welfare recipients to accept a new employment. While the RMI was a differential allowance (i.e. each euro drawn from work income was deducted from the allowance), the new benefit is only reduced by 38 cents for each earned Euro within the RSA scheme.

Both the French and the German dispositifs are market-oriented. They intend to avoid that MIBs prevent people from getting back to salaried labour. However, the instruments used for attaining this goal differ. None of them appears as more 'social democratic' or, in the opposite, more 'liberal' in the sense of the Esping-Andersen's typology. The German policy approach places greater emphasis on the work duties but grants a higher lever of income support. Duties have not the same importance in France, yet, in this country, the benefit level is lower overall while financial incentives to work more are strong. As a tendency, Germany is focusing on disciplinary methods while France has created a system based on financial incentives. Both countries have introduced or reinforced the respective instruments, although they have not the same importance. In that way, a similar evolution of MIB schemes in both countries has led to distinct answers regarding the same problem. Such variety provides an interesting soundboard for discussing welfare state models, at least for the case of unemployment protection. The specific political approach to welfare-to-work has called into question the idea of similar developments of Bismarckian welfare states, as put forward by many studies on this issue.

\section{Dualization: more than a common feature, a principle of distinction}

This paper has sought to show that MIBs have changed profoundly, with a marked transformation of their role in the overall welfare state as a consequence. The evolution of the dispositifs under study exhibits important common features which however cannot hide the emergence of significant new differences. Social policies, pressured by the growth and the modification of the population of welfare-dependent people no longer are mere instruments for supporting citizens with low income; rather, they have increasingly integrated elements typical of labour market policy. To a large extent, MIBs recipients have been redefined and categorized as jobseekers. Unemployment agencies are playing a central role in the follow-up of recipients. The techniques they use are not only aimed at promoting the social and professional integration of recipients through personal support. They are also geared towards restricting the potential negative effects these benefits may have regarding a return to employment.

The dualization of the unemployment protection schemes does not proceed by a mere extension of assistance schemes, but by the reorientation of poverty-related benefits. MIBs, originally conceived for protecting against poverty, have become instruments of labour market policy. A very large section of unemployed citizens (the lion's share of them as far as Germany is concerned) is now depending on these benefits. Dualization is a common feature of the French and the German welfare systems. It represents a path dependency in the sense that 
structural factors, and, first of all, the strong rise in unemployment, has provoked a turn to welfare assistance, hence to dualization. However, with dualization, the two welfare regimes are not governed by their former logic any more.

The reform orientation underlying this tendency of dualization can be read as a path departure in the two meanings of this term. The welfare-to-work policy is a strong political choice which does not seem to be driven by former institutional provisions in the two welfare states. Rather, the introduction of completely new instruments hints at deliberative path departure. The differences found within the Bismarkcian worlds of welfare suggest there is not just one but several ways to dualize welfare states. The financial incitements and the disciplinary techniques represent two governmentalities that make the French and German social protection clearly distinguishable. On the one hand, the French dispositif, principally founded on financial incitements, stands for a minimalistic approach in the sense that state intervention is limited regarding both paying benefits and demanding compliance with duties. On the other hand, the German dispositif, based on disciplinary techniques, is an example of a paternalistic way to manage labour market policies.

What is explaining these different path departures? This contribution does not provide elements to answer this question. As suggested by recent work on culture change and path dependency (Pfau-Effinger, 2008), the cultural background of each country could probably explain this divergence but more precise historical work is needed to confirm this hypothesis. That said, it is very important to take into consideration these different instrumental governmentalities of the MIBs, notably because they contribute to the (re)structuration of labour markets. In particular, they are playing a prominent role in the regulation of precarious employment. In the light of the importance that MIBs dispositifs have taken within the social protection schemes for unemployed people, the modalities of interventions represent an essential variable when it comes to the comparison of social protection systems. It should be used from now on for the analysis of the effects these dispositifs have on the lower strata within the labour market, exploring both structural consequences (on employment, labour, wages, etc.) and subjective influences (quality of life, self-esteem, happiness, etc.).

Anyway, the comparative study of poverty and precarious labour obviously has to pay attention to these new forms of state regulation. Admittedly, this study has concerned only two countries, yet France and Germany are both powerful European states that exert a strong influence on the European Union and on the their neighboring countries. They cannot be considered as marginal cases, then. Furthermore, this limitation does not call into question the finding that the evolution of MIBs has not occurred in a uniform way across all Bismarkian welfare regimes. Quite the reverse, this article calls for a more detailed exploration of the specific way this transformation is operated. An extension of the comparison to other states is needed in order to confirm (or refute) the propositions of this analysis.

Be that as it may, the latter demonstrates that, in contrast to many other studies, path dependency or the path departure is not a simple issue when it comes to Bismarckian welfare states. Some developments are convergent while others are not. Our analysis of the MIBs dispositifs shows the emergence of a new axiological rationality governing social policies. While France and Germany are sharing this value-oriented governmentality underlying MIBs schemes, aimed at 'conducting' the recipients into gainful employment, it would be misleading to posit that both dispositifs follow the same path. For the development and the reforms of the MIBs bear witness to a very dissimilar instrumental governmentality. The different techniques in used for 'conducting the conduct' constitute a fundamental factor of differentiation, offering a strong basis for distinguishing among Bismarckian social protection systems. 


\section{References:}

- ANGERMÜLLER Johannes and DYK (van) Silke, Diskursanalyse meets Gouvernementalitätsforschung: Perspektiven auf das Verhältnis von Subjekt, Sprache, Macht und Wissen, Frankfurt am Main: Campus Verlag, 2010.

- AUDIER Florance, DANG Ai-Thu et OUTIN Jean-Luc, "Le RMI comme mode particulier d'indemnisation du chômage » in P. Méhaut et P. Mossé (eds.), Les politiques sociales catégorielles. Fondements, portée et limites, Paris : L'Harmattan, « Logiques économiques », 1998 , t. 2, p. 124-143.

- AUST Judith. "Arbeitsmarktpolitik und Existenzsicherung ». In : Über Hartz hinaus: Stimmt die Richtung in der Arbeitsmarktpolitik? Düsseldorf : Edition Hans Böckler Stiftung, 2008.

- BARBIER Jean-Claude. "L'activation de la protection sociale : Existe-t-il un modèle français ? ». In : Anne-Marie Guillemard, (eds.). Où va la protection sociale ? Paris : Puf, 2008, p. $165-201$.

- BARBIER Jean-Claude. "Le workfare et l'activation de la protection sociale, vingt ans après : beaucoup de bruit pour rien ? Contribution à un bilan qui reste à faire ». Lien social et Politiques, 2009, $n^{\circ}$ 61, p. 23-36.

- BARBIER Jean-Claude, KNUTH Mathias, « Activating Social Protection against Unemployment: France and Germany Compared », Sozialer Fortschritt, 2011, vol. 60, n¹-2, p. 15-24.

- BARBIER Jean-Claude et Bruno THÉRET (2009), Le système français de protection sociale,

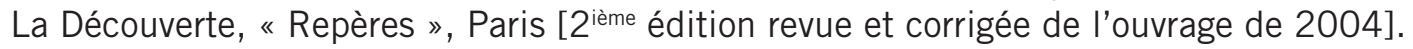

- BARBIER Jean-Claude, THÉRET Bruno, Le nouveau système français de protection sociale. 2e éd. revue et corrigée. Paris : La Découverte, 2009.

- BLESES Peter, SEELEIB-KAISER Martin. The Dual Transformation Of The German Welfare State. New York : Palgrave Macmillan, 2004.

- BOGET Yoann, "De la lutte contre la pauvreté à la régulation de l'emploi précaire : Une comparaison franco-allemande des effets de la crise sur les systèmes de protection sociale ", In BARBIER Jean-Claude, BRESSON Maryse, MULLER Béatrice (eds.) La solidarité à l'épreuve des crises, Paris : L'Harmattan, «Institut de la ville et du développement », 2013. (Upcoming publication).

- BOLTANSKI Luc and CHIAPELLO Eve, The New Spirit of Capitalism, London-New York: Verso, 2005 [1999].

- BONOLI Giuliano. "New social risks and the politics of post-industrial social policies", In Armingeon Klaus and Bonoli Giuliano (dir), The Politics of Post-Industrial Welfare States: Adapting post-war social policies to new social risks. Routledge, London and New York, 2006, p. 192-210.

- BRÖCKLING Ulrich, Das unternehmerische Selbst: Soziologie einer Subjektivierungsform, Suhrkamp Verlag, 2007.

- BRÖCKLING Ulrich, Krasmann Susanne and LEMKE Thomas., Governmentality: Current Issues and Future Challenges, New York, Routledge, "Chapman \& Hall", 2011.

- CASTEL Robert, Les métamorphoses de la question sociale, Paris : Fayard, 2005.

- CASTEL Robert. La montée des incertitudes : travail, protections, statut de l'individu. Paris : Éd. du Seuil, 2009.

- CASTEL Robert, DÖRRE Klaus, (eds.). Prekarität, Abstieg, Ausgrenzung: Die soziale Frage am Beginn des 21. Jahrhunderts. Frankfurt/M. : Campus Verlag, 2009.

- CASTEL Robert, LAÉ Jean-François, (eds.). Le revenu minimum d'insertion, une dette sociale. Paris : I'Harmattan, 1992.

- CLASEN Jochen, CLEGG Daniel. "Beyond activation: reforming european unemployment protection systems in post-industrial labour markets ». European Societies. 2006, vol. 8, $\mathrm{n}^{\circ} 4$, p. 527-553.

- CLASAN Jochen and GOERNE Alexander, "Exit Bismarck, enter dualism? Assessing contemporary German labour market policy”. Journal of Social Policy, 40: 4, 2011, p. 795- 810. 
- CONCIALDI Pierre. "Sozialmindestsicherung und Sozialhilfe: ein deutsch-französischer Vergleich ». In : Wolfgang Neumann, (eds.). Welche Zukunft für den sozialstaat? Reformpolitik in Frankreich und Deutschland. Wiesenbaden : VS Verlag für Sozialwissenschaften, 2004, p. 155-180.

- DARDOT Pierre et LAVAL Christian, La nouvelle raison du monde. Essai sur la société néolibérale, Paris: La découverte, 2009.

- DUFOUR Pascale, BOISMENU Gérard, NOËL Alain. L'aide au conditionnel : la contrepartie dans les mesures envers les personnes sans emploi en Europe et en Amérique du Nord. Montréal : Presses de l'Université de Montréal, 2003.

- DUVOUX Nicolas. L'autonomie des assistés : sociologie des politiques d'insertion. Paris : Presses universitaires de France, 2009.

- DUVOUX Nicolas. "Le RMI et les dérives de la contractualisation ». In : Serge Paugam, (eds.). Repenser la solidarité. L'apport des sciences sociales. Paris : PUF, 2007, p. 451-472.

- ESPING-ANDERSEN Gøsta. The three worlds of welfare capitalism. Cambridge : Polity press, 1990.

- ESPING-ANDERSEN Gøsta (eds.), Welfare States in Transition, National Adaptations in Global Economies, London: Sage Publications, 1996.

- FOUCAULT Michel, Il faut défendre la société : Cours au collège de France, 1975-1976, Paris : Seuil et Gallimard, " Hautes Études », 1997.

- FOUCAULT Michel, "L'éthique du souci de soi comme pratique de la liberté », Dits et Ecrits, tome II, Paris : Gallimard, «Tel », 2001 [1984], pp1527 -1548.

- FOUCAULT Michel, Sécurité, territoire et population : Cours au collège de France, 19771978, Paris : Seuil et Gallimard, " Hautes Etudes », 2004.

- FOUCAULT Michel, The Birth of Biopolitics: Lectures at the College de France, 1978-1979. New York : Palgrave Macmillan, 2008.

- KNUTH Mathias. " „Hartz IV“ - die unbegriffene Reform ». Sozialer Fortschritt. 2006, vol. 7, p. 160-167.

- KNUTH Mathias. "Zwischen Arbeitsmarktpolitik und Armenfürsorge Spannungsverhältnisse und mögliche Entwicklungen der ,Grundsicherung für Arbeitsuchende' ». In : Clarissa Rudolph, Renate Niekant, (eds.). Hartz IV: Zwischenbilanz und Perspektiven. Münster : Verlag Westfälisches Dampfboot, 2007, p. 66-91.

- LESCHKE Janine. Unemployment Insurance and Non-Standard Employment. Wiesbaden : VS Verlag für Sozialwissenschaften, 2008.

- MARQUARDSEN Kai. "Was ist «Aktivierung » in der Arbeitsmarktpolitik? ». WSI-Mitteilung, 2007, vol. 60, n 5, p. 259-265.

- MAUGER Gérard., "Les politiques d'insertion », Actes de la recherche en sciences sociales, vol. $n^{\circ} 136-137,2001$, p. 5-14.

- MÜLLER Kai-Uwe, OSCHMINASKY Frank. "Die Sanktion der Arbeitsagenturen: Eine empirische Analyse zu Sperrzeiten ». In : Kogler Schütz, Hugh Mosley, (eds.). Arbeitsagenturen auf dem Prüfstand: Leistungsvergleich und Reformpraxis der Arbeitsvermittlung. Berlin : Edition Sigma, 2005, p. 95-134.

- NEUMANN Wolfgang. "Beschäftigung und sozialer Zusammenhalt: ein Vergleich der Arbeitsmarktentwicklung und Arbeitsmarktpolitik in Frankreich und Deutschland ». In : Wolfgang Neumann, (eds.). Welche Zukunft für den Sozialstaat? Reformpolitik in Frankreich und Deutschland. Wiesenbaden : VS Verlag für Sozialwissenschaften, 2004a, p. 9-21.

- NEUMANN Wolfgang. "Einleitung ». In : Wolfgang Neumann, (eds.). Welche Zukunft für den Sozialstaat? Reformpolitik in Frankreich und Deutschland. Wiesenbaden : VS Verlag für Sozialwissenschaften, 2004b, p. 9-21.

- OSCHMINASKY Frank, KAPS Petra. "Ein System für alle erwerbsfähigen Hilfebedürftigten? Das SGB II und seine Schnittstellen zu anderen Sozialgesetzbüchern ». WSI-Mitteilung. 2009, n 8, p. 439-445.

- OSCHMINASKYFrank, MAUER Andreas, SCHULZE BUSCHOFF Karin. «Arbeitsmarktreformen in Deutschland - Zwischen Pfadabhängigkeit und Paradigmenwechsel ». WSI-Mitteilung. 2007, n 6, p. 291-297. 
- OUTIN Jean-Luc. "La contrepartie : introduction ». La Revue Française des Affaires Sociales. 1996, n 3, p. 3-10.

- PALIER Bruno, MARTIN Claude. "Introduction ». In : Reforming the Bismarckian welfare systems. Oxford : Blackwell, 2008, p. 1-20.

- PALIER Bruno (eds.). A Long Goodbye to Bismarck? The Politics of Welfare Reform in Continental Europe, Amsterdam: Amsterdam University Press, 2010.

- PAUGAM Serge. La disqualification sociale : essai sur la nouvelle pauvreté. Paris : PUF, 1991.

- PAUGAM Serge. La société française et ses pauvres : l'expérience du revenu minimum d'insertion. Paris : PUF, 1993.

- PAUGAM Serge. Le salarié de la précarité : Les nouvelles formes de l'intégration professionnelle. Paris : PUF, 2000.

- PAUGAM Serge. Les formes élémentaires de la pauvreté. Paris : PUF, 2005.

- PAUGAM Serge, Duvoux Nicolas. La régulation des pauvres. Paris : PUF, 2008.

- PAUGAM Serge, MARTIN Claude. "La nouvelle figure du travailleur précaire assisté ». Lien social et Politiques. 2009, $\mathrm{n}^{\circ}$ 61, p. 13-19.

- PFAU-EFFINGER, Birgit "Culture Change and Path Departure: The example of family policies in conservative welfare states", in: W. v. Oorschot, M. Opielka and id (eds.), Culture and welfare state. Values and social policy in comparative perspective. Cheltenham, Edward Elgar, 2008, 185-204,

- PIERSON Paul (eds.), The New Politics of the Welfare State, Oxford: Oxford University Press, 2001.

- POLANYI Karl. La grande transformation : aux origines politiques et économiques de notre temps. Paris : Gallimard, 1983, [1944].

- SCHULDT Karste. "Aktive Arbeitmarktpolitik nach den Hartz-Gesetzen ». In : Jürgen Klute, Kotlenga, (eds.). Sozial- und Arbeitsmarktpolitik nach Hartz: Fünf Jahre Hartzreformen: Bestandsaufnahme, Analysen, Perspektiven. Göttingen : Universitätsdrucke Göttingen, 2008, p. 61-73.

- SCHULTHEIS Franz. "L'Etat et la société civile face à la pauvreté en Allemagne ». In : Serge Paugam, (eds.). L'exclusion : l'état des savoirs. Paris : Éditions la Découverte, 1996.

- SCHULTHEIS Franz. "The European Strategy of Employment : Between Fighting against. Precariousness among the Youth and Producing more Flexibility", In Swiss Journal of Sociology, vol. 30, n³, 2004, p. 303-318.

- SERRANO PASCUAL Amparo and MAGNUSSON Lars (eds.), Reshaping Welfare States : Activation Regimes in Europe, Brussels: P.I.E. Peter Lang, 2007.

- SIMMEL Georg, "Der Arme", Chapter 7 in Soziologie: Untersuchung über die Formen des Vergelleschaftung, Leipzig: Dunker und Humboldt, 1908, pp. 454-493.

- TRICKEY Heather, LØDEMEL Ivar, (eds.). An offer you can't refuse: workfare in international perspective. Bristol : the Policy Press, 2000.

- WOLFF Joachim, HOHMEYER Katrin. "Förderung von arbeitslosen Personen im Rechtskreis des SGB II durch Arbeitsgelegenheiten: Bislang wenig Zielgruppenorientiert ». IAB Forschungsbericht. 2006, $\mathrm{n}^{\circ} 10$.

\section{(Footnotes)}

${ }^{1}$ The average housing cost is calculated by relating the number of people in the family to the average housing costs per person (source: BMAS). In reality, these costs are probably higher for a single person and lower for a big family. 